\title{
Writing resistance together
}

\begin{abstract}
This piece of writing is a joint initiative by participants in the Gender, Work and Organization writing workshop organized at Hanken School of Economics in Helsinki, Finland, in June 2019. This is a particular form of writing differently. We engage in collective writing and embody what it means to write resistance to established academic practices and conventions together. This is a form of emancipatory initiative where we care for each other as writers and as human beings. There are many author voices and we aim to keep the text open and dialogical. As such, this piece of writing is about suppressed thoughts and feelings that our collective picket line allows us to express. In order to maintain the openended nature of the text, and perhaps also to retain some 'dirtiness' that is essential to writing, the paper has not been language checked throughout by a native speaker of English.
\end{abstract}

Key words: writing, co-writing, resistance, feminism

\section{Where to begin?}

'Writing is a form of collective resistance for Gender, Work and Organization.' This sentence was given to us, a group of junior, mid-career and senior academics, as an inspiration for developing a collective piece to reflect on our writing practices as academics. Sitting in a room in Hanken School of Economics in Helsinki in the frame of a 'Writing differently' workshop, we use the space of our round-table discussions and the materiality of it to rethink 
academic writing as a form of collective resistance (cf. Grey \& Sinclair, 2006; Gilmore, Harding, Helin \& Pullen, 2019; Helin, Harding \& Pullen, 2020). We intend to challenge patriarchal standards - academic jargon, stiff paper formats, narrow fields, quant focus, publishing cartels, formulaic research, gendered review processes and so on - that shape academia and constrain our ability to write meaningfully as academics. After a short roundtable discussion, the point was clear: we desperately need a space to breathe, to move beyond the boundaries imposed on us by the disembodied metrics that are put into place to evaluate our 'intellectual' abilities as academics. These favor quantity devoid of meaning in our academic production as opposed to impactful, meaningful knowledge.

The approach to writing we took is experimental, collective and emerging. The idea for the piece came from Alison, a Joint-Editor of GWO, during our two-day workshop: bottom up, using our voices as authors in a large group of scholars of different nationalities in different career stages. First, we divided our group of 22 participants into four smaller groups where we discussed our broad theme 'Writing as a form of resistance' for about an hour. Each group identified their own focal themes (silence, blindness, the five senses and so on) which they then developed further. We returned to the small groups the next day when each participant had had a chance to experiment with the theme, think and pen down a sample of writing, and we continued the discussion that was more like brainstorming where we shared our writings. Then, each group shared their ideas with the larger group. Before breaking up, we decided that all participants would write a short text of their own. Each group chose a person responsible for collecting the texts, and one person volunteered to create a structure in google doc for all the groups where we could all see the collective work that is like a quilt of different styles and musings. What are we as critical scholars 'resisting' and how does our collective thinking and writing reflect it? This is what we are going to discover. 
By writing this piece collectively, we embody and convert our individual struggles and blockages to words. We put our women's and men's bodies in our texts: hairy, raw, stinky and leaky as they are (Pullen, 2018), to create a common language and through this engage in collective action. We use our individual 'I's and subjectivities with all the peculiarities, emotions, messiness, fragility and vulnerability that they carry to construct a sense of weness and togetherness. We do not only write for each other but also with each other experiencing our ontologies processually and becoming together in connection (Ettinger, 2006; Kenny \& Fotaki, 2015). We relate, we care, we take care, we make space for our differences, we connect...we dialogue. We agree and disagree.

As Helene Cixous said, we just need to write. And write about writing, we add... we just need to write from our women's (and men's) bodies and for them...We are women and men but allow our feminine sides to emerge. By feminine we denote not the materiality of our bodies but our ability to shake the symbolic order by crying and laughing where silence 'has to be' respected, as Cixous calls for in the 'Laugh of the Medusa." We are 'bi-sexual' and we write as such: bi-sexually to find a common voice and raise it (Cixous, 1976; see Phillips, Pullen \& Rhodes 2014).

We join in academic accounts calling for the need to rethink writing as a creative process, and accounting for the embodied, affective, and reflexive experiences of the author/s (Pullen \& Rhodes, 2008; Helin, 2019; Pullen, 2018; Kiriakos \& Tienari, 2018). This is a process that is about what we feel, not only about what we know or think (Rhodes, 2015; Amrouche, Breckenridge, Brewis, Burchiellaro, Breiding Hansen, Hee Pedersen, Plotnikof \& Pullen, 2018). It is not a literature gap that our text intends to fill but rather an intention to challenge 
prevailing conceptions of academic writing and call for changing the way we think of and relate to it. In this creative process, we open up our bodies to make space for an ethical connection with our readers and the subjects that we write about (Fotaki et al., 2014). We use our writing to speak, to connect, to challenge, and to resist together. We use our writing to overturn the higher order pedagogies that suppress our 'un-disciplined' bodies in the context of academic practices (Bell \& King, 2010; Thanem \& Knights, 2019).

We know that challenging academic practices and conventions of writing will be a long process, a long journey, a battle that may be lost. But we do not stop. We continue... We take the freedom to do it differently, without asking permission for this anymore. Just doing it...differently! And we do it for the 'I', for the 'you' and the 'us.'

\section{Silence and silencing}

\section{Beginning}

The group assignment starts. We sit at a round table. Six of us. In silence. People waiting for someone to express their thoughts. Silence. The conversation begins slowly. It is about silence. It is about trust, equality and care that slowly builds around us. It is about writing, listening and agency. Passive and active voices. About personal and collective struggles. About vulnerability. Being exposed, available, open. A rupture. The space that breaking apart creates for building a community, and for writing that enables us to challenge the status quo of the standards of academic writing. But we keep returning to silence. Our own silence and the silence of others through our writing. How can silence be resistance? Written in the unspoken spirit of love, here is our joint endeavor to understand the power(s) of silence through embodied writing. 


\section{Incomplete}

Words through my body.

Text without pre-reflection, against everything I've been taught in academia.

Can I resist the urge to modify?

To add?

To make it complete?

Rational, neat and nicely structured.

Complete for who? Reviewers? Editors?

For an audience.

Complete in format or in message?

The audience will notice that the text is incomplete.

They will notice I am incomplete.

\section{Exploring the power of silence}

As academics, we enjoy the privilege of empowering others by 'giving voice to the marginalized.' Yet, what we rarely talk about is the moments when we either choose to or feel compelled to keep silent. In the workshop, when we began to discuss this notion of silence, relating to our identity as women in a male dominated industry, to being non-native English speakers but feeling the pressure of publishing in English... we decided to dig deeper into the notion of silence and to explore the power of silence.

Buddhist philosophy gives a lot of insight about silence. In Buddhism, the goal of life is the act of living it. On the one hand, silence is regarded as the expression of knowing and the inaudible manifestation of frailty of words. On the other hand, the language of silence is capable of dispelling one's inner darkness, anxiety and void. Hence, silence, in Buddhism, is 
an inherently powerful action for pursuing the Truth. It is itself the Truth. Truth cannot be defined or explicitly described but can only be experienced. Truth cannot be communicated with words, but only be shared with people who are willing and capable to embrace it into their own beings.

Recognition of moments of silence is central to our collective project. By deliberately elaborating the emotional and embodied experience hidden behind these moments of silence, through flashing out the unspoken words interwoven in silence, we want to connect, relate and affect each other. In this writing, we give silent moments voice. The inaudible voices shall pass on important messages which many times we would like to cry out, but there is fear to be heard. I believe that we can forge a collective resistance to this highly masculinized culture in academia where control, competitiveness, aggression, power and success are overrated, and any sign of vulnerability is strictly repressed.

The silence that is known to most of us is its exterior absence of words. Although in such moments, words are not used yet, our minds are unquiet. They are filled with emotions, ideas, frustrations, desires, creativities and doubts. We choose or are compelled to keep silent when we realize we are the only woman in 'men's space,' and being foreign in a country where we are always identified as a member of different others, when we are put up as a token of the marginalized group, when we feel overwhelmed by senses of insecurity:

\author{
I sometimes choose to keep silent in academic conferences when I am not \\ sure about the climate in which the discussions are taken. I guess I am unsure \\ of whether it is a space in which my thoughts and arguments will be \\ appreciated, understood and how others will react. Maybe it is personal \\ insecurities. As said, sometimes I fear others' reactions, because, in my \\ experience, they are not always friendly. I might feel frustrated as I already
}


know that I do not have anything to contribute to a discussion if it takes a certain track and tone. I might feel an urge to voice my thoughts, even if I know the risks of how it might be received, depending on my own state of mind and strength, a question arises: do I open my mouth? What do I think about? The things that should be said. The things that should be challenged. The things that have not changed. But what do people think of me saying those things out loud? Who I am to say so?

I am a person with a lot of words. I enjoy expressing myself, my feelings, and opinions. But I have learnt to keep silent. I choose silence when I realize I am fighting a hopeless war where important decisions are made for me and others. I have learnt that silence is my safeguard. I think when I do not speak ...

I'm not sure I ever really choose to keep silent, but rather feel compelled to by outside forces. Lots of times I am thinking about so many other things that I can't fully participate in the conversation. Sometimes I am silent because I have nothing to contribute, because I am opposed to the topic or the line of inquiry or the analytical frame, but I don't have the position or status to challenge those who lead the discourse. What do I think about when I am silent? Everything else. My body, the air, escaping. I imagine other people, other places, the dead. Things that smell nice. Food. I often think of eating and drinking. How I feel when I am silent? Private, and attending to my own self. When I speak, I feel as if I am floating and often that my voice is coming from another body. In silence I connect to that voice, and I can hear it in various ways. 


\section{Relating}

Academia is full of useless noise and meaningless words.

Everyday it's getting harder to breathe.

Silence is a scream for pause.

Silence is harmony.

Silence is respect.

Silence is beauty and wisdom.

In silence, we open up and become more sensitive to others' vulnerabilities.

In silence, we relate.

\section{Sounds of silence}

The music flows around you, echoing between the stone walls of the church. The voices of the singers of the excellent choir following the gentle instructions given by the aging conductor. The singers individually performing the ancient texts, their bodies breathing together, and sounds intertwined. Listening tentatively, ready to be moved, touched, to engage in the music. Then the music suddenly, unexpectedly stops. The conductor suspends her hands mid-air. The silence happens. A rupture in the flow of music. And we wait, listening to the silence. And just when we cannot bare the silence any longer, the hands of the conductor shift and the sounds of the human voices return. This indefinite rest in the music is called a general pause or a grand pause. This silence in the middle of the flow of music is a powerful tool to mark a change, a shift in the temporality of the music. It is, in particular, its unexpected nature and the non-defined length of this suspension that makes the experience so 
powerful. Sometime the musicians hold the pause 'too long' and someone in the audience will think that the piece has ended and starts to applaud. Perhaps we would need to think more carefully about the person who applauds, breaking the silence. What is it in the prolonged silence that forces us to take action?

Or in the words of Paul Simon:

'Fools,' said I, 'You do not know

Silence, like a cancer, grows

Hear my words that I might teach you

Take my arms that I might reach you'

But my words, like silent raindrops fell

And echoed in the wells, of silence

\section{Subjectivities}

Please excuse my silence, which is not meant to be a slight. And I fear you will interpret it as laziness, flightiness, artlessness. But really, I was just existing as my other self, the one who attends constantly to the needs of my children, husband, family, friends, home, dirt, dust, items, empty tummies. Last week, when I met you, I was the self who thinks deeply about what's wrong with the world and why. That self who has time to ponder big questions, and can't shut up once the mouth gets going, with ideas overlapping, feeding each other, getting tangled and complex and so very interesting. The self with capacity to collaborate. But, too much time being that one has consequences - coming home to a messy house, everything and everyone needing attention, straightening up, making proper food, helping with homework, driving them around. Just the routine stuff, but there is so much of it, and it takes time. And 
hence the silence from my academic self - no time to sit down and let the words flow - until it's so late that I am half asleep. Then, my eyes droop and I can hardly even move my fingers over the computer keys.

So, although my academic self, far away from home, can acknowledge the strength of:

Silence in words, resistance for agency

Amongst dominant forces, withholding secrets, subject to misinterpretation

\author{
Absent presences \\ What is unsaid still permeates the air, it is \\ something that haunts and it connects us to histories of being oppressed
}

What comes out when I am at home is this notion of being silenced by the second shift, being silenced by my expectations for myself as a mother, a partner, a domestic laborer and by their reliance on my having those expectations so they can exist in an orderly and pleasant home.

Together, in Helsinki, we talked about the power in silence, opting out, not participating. My silence today is not voluntary, it is done to me and holds me back. But, as someone who loves me says to me: 'you chose this.' At the time, it did feel like a choice - to get married, to have babies... but everything that comes with it is a requirement. Then, tracing back to the original 'choice's: every time my child self, pictured my adult self, I saw a nice house, a nice kitchen, nice garden, nice children, me waiting for him to come home from work. I saw my self, in what I saw, every woman around me doing, when I saw the right way to be woman.

'Why do you want to be a scientist? How about a nice little kindergarten teacher?' 
'You are such a cute little scientist. Do you want to go out on a date? Do you want to get married and help me with my science?'

\title{
(STOP writing, look up)
}

\begin{abstract}
'Mom can you help my friend with a math problem?' And again, I am silenced, listening to the voices in my head that I can't find the time or place to let out. Please excuse my silence, I think (I was listening) to myself.
\end{abstract}

\section{Silence/voice}

Who do we silence in the current academic writing practices?

Our embodied voices through review processes, self-censorship and the strict conventions that we follow while constructing ourselves as 'scientific'.

Our struggles as academic scholars, as neatly functioning parts of the publishing machine.

(Be careful, do not let anything leak out!)

What about other experiences?

The ones we do not often write about?

The ones who's texts we do not read.

The ones who do not write.

The ones who are not taking part in these conversations, as in this room on June $7^{\text {th }}$ in Helsinki.

Writing as a form of collective resistance. Silence as a form of collective resistance. Politics of representation and the question of who speaks for whom. Play of voices and silence in the classroom. 
Silence can be used strategically as resistance.

But you need to have possessed a voice before you can use silence as resistance?

If you are absent and silent in a conversation, are you there to resist?

Questions of voice and silence.

Questions of production and consumption.

Of knowledge.

Of representations.

I consume and produce. Consume and produce. Consume and produce..

Where does my responsibility lie?

In my production. In my consumption.

Of I and the Other.

Quite obviously.

In the text.

In the silences of the text.

But how to enact it? How to be responsible?

How can I write and listen in a form that emphasizes the agency of others?

Staying attuned to multiple struggles, flows across, shows the different faces of silence.

Coming from yourself - empowering, comforting, joyful, sacred.

Coming from others - unjust, oppressive, disabling, lonely.

Strength and vulnerability of embodied silence. 
Consumed and produced. Consumed and produced.

Unequally.

How do we come together, and from multiple local struggles, form a collective resistance?

Has also the collective solution become silenced? No. Yesterday we started a process of dialogue and exchange as a foundation for this, based on our individual voices and the physical act of writing. Midst of the voices in the classroom, I sense, it is the fleeting moment of picking up a pen or starting to type - in awareness of our interconnection with others from where the moment of ethical action rises and we can see how some struggles might be silent, but others are loud, if we only know how to write them.

\section{Silence, again}

Years spent mute.

Grounded to the chair, only fear.

Fear of what may surface, if I speak.

Contained in thought and body,

It is the way for women.

Years passed, words appeared one-at-a-time.

Observing the silent cast adrift, and often drowning, in a sea of dominant male voices,

My voice, trembling and embodied, became more articulate,

But, how, can I stop? I fear that if I stop, I may never speak again. 
These lips of mine, in their plurality, have stories to tell.

Now others listen, cite and act on my words,

Fear of being quoted, reduced to a part of my being.

Controlled and contained, again.

Can women ever speak freely?

Lips enable connection, care and relationships - and resistance.

Silence ruptures male spaces.

Listening as a politics of care, of resistance.

Academia privileges those articulate subjects.

Time to hear the silence, hearing through the skin.

If we listen, what collective resistance is possible?

Every so often, silent bodies connect, words whisper, resonate with others, and I become me... this is the power of the masses. Sometimes these whispers connect, subversive, and the rage becomes her.

\section{Blindness}


Love is blind, or so they say. Violence is often blind, too, and that is what's so scary about it. The system of academic writing is based on blindness. Its review processes are a smokescreen for politicking, an illusion, a lie. From the shadows, the chosen few are elevated into the light and the rest of us are left behind and forgotten.

Let's have some names then! After each review process, accept or reject, let's have some names! Let those wonderful and generous people who help and support others come forward, into the light. And let the violent ones be named, too.

\section{Blindness around us}

Part I - Attack

Sometimes $I$ just shut up

Not talk, not write, but I always think...

It was a vertical moment

Blindness around us

A silently brutal stab

towards our work, us

- dangers of researching differently

Stupidity of

simple-minded thinking

kind of blindness, too

feminists, childbirth,

profit of researching certain topics 


\author{
HAHA! \\ Could you please shut up? \\ Sometimes \\ silence is sophisticated wisdom \\ Hiljaisuus \\ ...miten kaunis sana ja tila! \\ Feeling empowered
}

by the pathetic attack

This is who I am

our writing is us

Vulnerability

and sensitivity towards life around me

are my strengths

my inspiration

and my sources of

researching differently

Part II - Aftermath

Tears,

keep coming. Let them flow, flow, flow 
I've created a scene

anyway

Exposing my vulnerable

leaky

crying-like-a-little-child-kind-of body

to others

But crying is healing

écriture féminine

remains a tricky project

blind academia

with its 'neutrality' and narrow frameworks

dislikes disruptive, destabilizing

transgressive

écriture féminine

as a way to

confuse boundaries

or liberate our work from the standard research practices

Kind eyes, warm hugs

mobilize collective affects

Action! \#snaptivism 
Solidarity. Care.

We're in this space, together

Strength to keep writing

While academia continues

to limit my research

as well as 'free' it

and the ways in which the gendered body writes

Coda - Healing by writing together

Tilltufsad fjäderskrud

Hetkellinen siipirikko, lamaantuminen

Vai sittenkin jotain muuta?

Sara Ahmed, Hélène Cixous, Veena Das, Elspeth Probyn,

Tack skall ni ha!

Injurious norms, interrupted

Kvinnor som lyfter andra kvinnor

acknowledging our male allies, too

Freedom, flexibility, provocativity

without hurting

Rakastan akateemista työtä 


\author{
Kindness \\ Generosity \\ Care \\ Nei momenti complicati \\ è bello guardare dentro un armadio \\ pieno di sogni.
}

Ga je mee?

Affective suffering as

a pivotal moment

for transformation

Siamo insieme

tässä hetkessä

Vis-à-vis, allons-y!

What if our writing

makes the contribution (sic), that disrupts the

twisted, dull, gloomy

thinking and writing

in academia

reaching beyond seemingly narrow topics 
carefully scratching the polished surfaces

getting our feet dirty

appreciating the mundane rhythms

experiencing our sensory,

more-than-human life worlds

which, in fact, touch e v e r y t h i n g around us?

We keep writing together.

We rise by lifting each other.

Writing

as a beautiful form of

collaborative resistance

towards mental violence

and disembodied

detached

rigid

research

in academia

\section{Epilogue}


The two of us have written together for eight years. It was an instant 'click' between us, a sense of meeting another researcher and woman who feels you, understands you and respects you. Sisters in academia. Support. Genuine goodwill. Our collaboration builds on both mental and kinaesthetic empathy. For us, writing together works as a collaborative resistance against blindness in academia. Blindness which, for us, materializes in cynical thinking and denigrating attitudes towards 'marginal' research topics, complicated and sometimes irrational review processes, and the inability to see worth in other than cleaned-up writing that so firmly believes in objectivity, rationality and abstraction. We resist this blindness by keeping our writing simple, direct and vulnerably alive.

[INSERT PICTURE 1 HERE: A POST-IT NOTE THAT MATTERS]

A picture of a post-it note from the whiteboard at the workshop, captured by one of us. None of us wrote it and its writer remains a mystery to us, but we can thoroughly relate to it. These words resonate with the various sensations that writing evoke in our bodies, and foregrounds the aspects of 'wanting to communicate, to talk, to share, to interact' at the very focus, as we do in our academic work.

We are using writing as a collective means to resist the illusion of blindness in academia. With the concept of blindness we refer to a variety of academic practices aiming at anonymity and impersonality. They exist for good reasons: first, to emphasize that what is being argued is more important than who is making the claims and second, to assure fair and 
equal treatment of scholars and their texts. Despite good intentions, the blindness is an illusion, even a lie.

This blindness of practices means that the authority, expertise, gender or position of the author should not influence the assessment of the manuscript and the related decisions. However, in reality everybody, who has worked in academia for some time, has experiences that make one doubt the objectivity or anonymity of the processes. Humans as we are, we continuously search for cues of who the 'anonymous' are and make interpretations of the people we are dealing with. Many of us play on a rather small sand box, which makes it difficult not to know, who the other players are and what they do. In many cases, the processes are not blind; they only narrow down the number of potential people. Whether that is a problem or something to sustain is hard to say, but if the idea of 'blind review' indicates that anonymity is necessary for us academics to make fair and ethical assessments and decisions, is it credible to claim we are fair and ethical behind the curtain of anonymity? Rather, the blindness of academic practices acts as a script that makes the political games less obvious and difficult to trace down.

In academic writing, the tradition of neutrality and impersonality has led to writing becoming a non-contextual, impersonal and universal practice, in which the author has to hide him/herself and his/her personality, mother tongue, context, history and body. We are expected to write as a universal academic - supposedly a white male from an Anglo-Saxon country. Thus, writing as a blind practice not only causes all academic texts to be alike and restricts freedom of expression, but also disconnects the readers from the actual process of producing texts and the person doing it. It enforces the appearance of objectivity, expertise 
and truthfulness, while making academic texts clinical, often formulaic and empty of any deeper meaning.

\section{Unblinding an aspiring scholar}

In case you are expecting to join the Temple of Knowledge: wake up! If you yearn to meet Wisdom in people who would sell their soul to devil to know-it-all and to find a miracle in a falling apple: unblind yourself! You are likely to become a basic unit of production in a sloppily managed factory that will turn your natural inclination for curiosity and experimentation into process waste.

On the factory floor, people who tend to think, act and write alike establish rank and superiority by competing to see who can piss the farthest. The great task is to determine who publishes the most in places some obscure parties with power and vested interests have defined as 'best' and others have accepted as 'mandatory.' For sure, one can win because one is hardworking and talented but also because one is skilled at all sorts of misbehavior or eager to massage the fragile egos of the members of the ruling party.

This is a ruthless hunger game that is dominated by a conservative establishment against which the other groups, including the self-proclaimed critical ones, timidly position themselves. Dissidents say 'the system,' 'patriarchy,' 'neoliberal university,' or 'western hegemony' makes them and nothing can be done. Slowly, you may start believing in this, citing Foucault or something else sophisticated to exempt you from personal responsibility. 
Becoming a PhD-student means low levels of autonomy. The precarious employment conditions would cause an uprising anywhere else. Whether you receive a position or a grant or support of any kind, depends almost entirely on the whims and competence of your supervisor- or any other patron you may find who happens to like you. Many fall into oblivion or predatory, abusive relations. Some are left spinning alone, some drift away fighting severe depression.

With time the imagined Temple inevitably crumbles down - and may become a labyrinth you cannot exit as your mind is trapped inside. You will find some genuinely intellectual individuals, and that is when light shines onto the factory floor. However, they may not take interest in your magnificent drafts, philosophical insights and brilliant ideas - they have their own battles to fight and demons to face. Your likely destiny is either exit or becoming a unit of production like most other technician-researchers on the factory floor.

\author{
I am still here because despite all this, academia can be an addictive, fascinating place if one \\ can develop a somewhat functional existence in it. Many won't. I must have some \\ undiagnosed obsessive-compulsive disorder and want to be part of something that is \\ important to me that I want to defend and that I cannot define with words.
}

\title{
Writing is a form of collective resistance
}

I knew that I was not for this. I didn't just want to choose for myself a spacious cell in a comfortable prison. I preferred a slam in the open air, feeling the sun 
and the rain nourishing my skin and then writing about it. To let my body breath more fully, to take the air down to feel my belly moving, to fill my lungs with the oxygen that I need to be able to continue living... and thus writing...or is it the other way around?

Writing is personal. It begins with a person and it ends with a person. You can call one a writer and the other a reader, but it may not be so.

\begin{abstract}
Writing is collective. It begins as a relationship between people and it ends as a relationship between people. You may call one a text and the other understanding, but it may not be so.
\end{abstract}

Writing is political; it produces knowledge. Writing is political; it challenges knowledge. Writing as resistance is personal; you object, refuse, insist. Writing as resistance is collective; you examine, influence, organize.

Sometimes it is important to resist writing, when the politics of writing are such that the text is no longer the purpose of writing, when writing has become divorced from the text and only the mere existence of the text is its purpose.

Writing is a form of collective resistance. Writing as a form of collective resistance is writing that examines, also, itself, is suspicious of itself, examine its own assumptions without turning on itself and without turning in on itself. Writing as a form of collective resistance cannot be about itself. 
Academia is no longer what it used to be. We are operating during a time where the ability to predict consequences and possible results of research projects are decisive for managing the academic everyday, including the possibility of attaining research funding. To make sure we are not hit by surprise we can never lose control of our direction, or force forwards. To that aim we have to write from that which we already know, turning writing into a machinery practice as we write in under publication pressure. Writing becomes fragmented, flat, disembodied, and it is lacking depth just as the horizontal arrow that symbolizes this view on time.

At its worst this work hurts me, this work makes me cynical and angry. It makes me not want to write anymore. It makes me want to resist it.

\section{Questioning}

What is the power that writing resists? Is it more writing, other writing, competing knowledges? How does writing resist? What is the principle with which it resists? With new words, with new voices, with new forms, with new languages. Can those be heard?

\section{Ok. At least writing does not kill, does it?}

I get distracted by a message from Facebook and start surfing. There has been another unfounded arrest of an investigative journalist in Moscow. A picture of protesters catches my eyes. People are standing in line in order to hold a single picket. One by one. Unsanctioned collective political rallies are forbidden in Russia, and concerning this case, there is no chance a permit would be issued. A single picket is the only legal way to resist. Therefore, all 
these persons are waiting for their turn to hold the poster with a call to free the journalist. They are together, but, at the same time, each one adds her or his own voice to the common cause.

The pen is heavy.

The screen is blank.

Is there space for me here?

Am I experienced enough? Am I legitimate enough? Am I powerful enough? Do I need permission for this? From whom? For what? Where am I (hidden)? Where is my body? Where is my sensuality, my affect, my rigidity, my fragility, the messiness that I carry? Why do I do this and for whom?

Should I first learn to publish more traditionally before beginning to resist it? I'd rather still write differently, because it's more fun, more lively, more something I want to do, but will I succeed to publish by doing so?

\section{Resisting prevailing forms of academic writing and resisting that resistance}

I am joining the line of those who are determined to write differently, 'acknowledging the risk of embarrassment, of not being understood, of being dismissed or ridiculed, of being considered self-indulgent, or of being rejected' (Kiriakos \& Tienari, 2018: 266). While staying in the line, I am summing up what seems important to me in writing and formulating it as a manifesto, as suggested by Jenny Helin at the GWO workshop. 


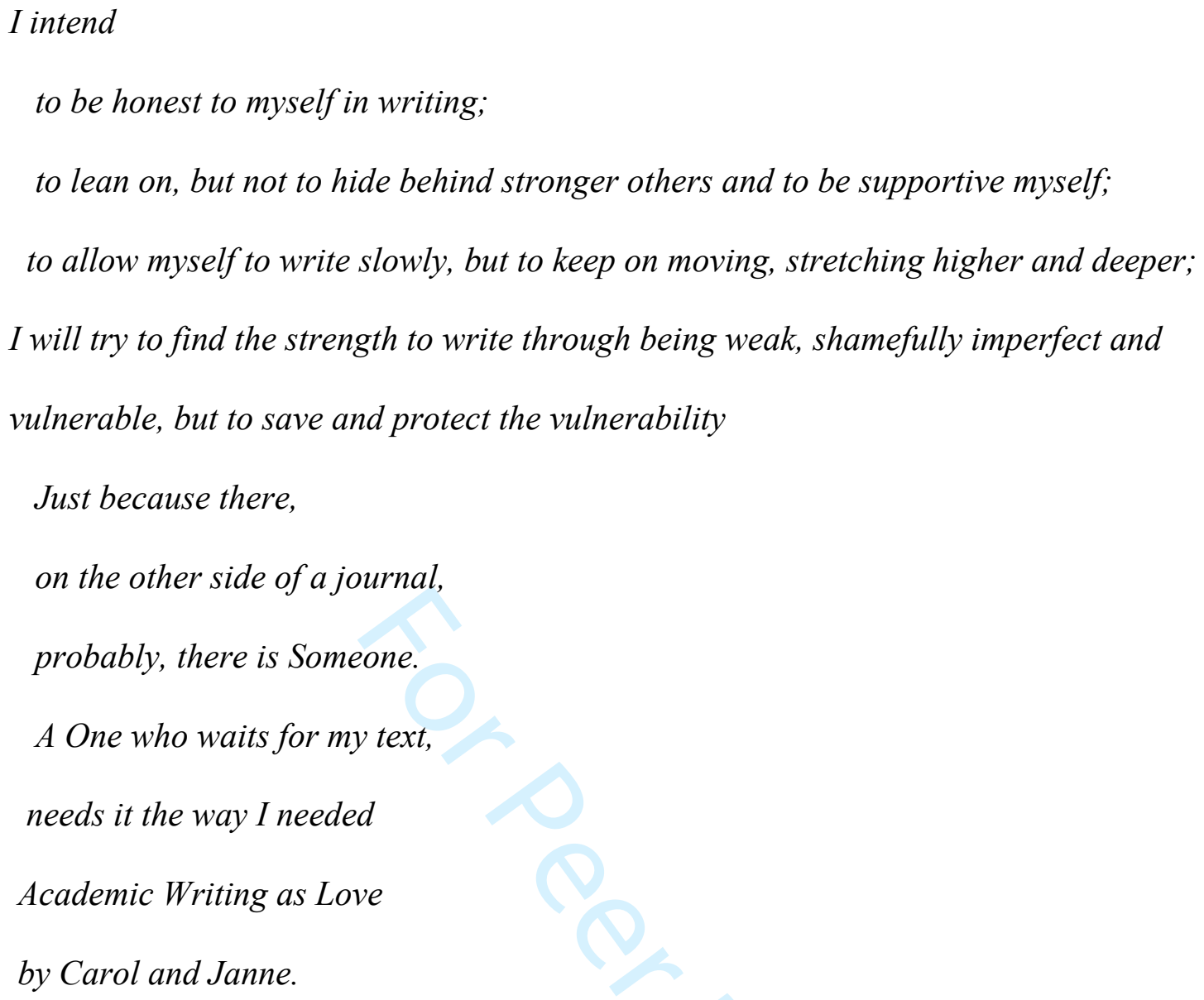

No, no, I will not. I will not participate in this collective resistance thing. I am not yet there; I have not yet learned to fill the gaps properly. Besides, they all are so cool, and experienced, and 'vertical' in writing, and so poetic.

I keep staring at Carol Kiriakos and Janne Tienari’s article 'Academic Writing as Love'. I see writing as a long-term relationship, in contrast to writing as passion and competition. I do not like the idea of participating in the race. It does not inspire me, this race, which suggests no space and time for dealing with being weak and vulnerable, being attentive and protective to others. 
"You see. Love has been conceptualized for you personally. Have you not been looking for it? Just take it”.

I find it difficult to find the balance between peaceful me and collective resistance. As I see it, the 'battle, fight, protest, resistance' -rhetoric is about looking for courage in myself to oppose dominating power. However, opposing is not the aim in itself.

All these are questions that have been circulating in my head since the early years of my PhD, unsettling my few hours of rest, the endless nights that I spent alone after long days of developing rigorous argumentations and deductions of 'counter-intuitive' (but otherwise soulless) hypotheses for my academic texts. What a word! Counter-intuitive! it has to be so to 'sell'... just doing the intuitive is not enough.

Just writing is not enough! ... for what really matters!

For years, I kept my body constrained; limiting it from its potential to express what inherently inhabited it... ideas, dreams, sensations, pleasure, pain, worries, confidence or lack of it...I held back from writing a language that touches, to write about a topic that touches, to write about writing itself. I kept all of this for my personal scripts, which I had very little time to care about. And I was afraid of sharing these concerns with my supervisors or colleagues, in fears of being seen as the crazy one.

Vulnerability in academic criticism... In fear of being rejected...Yet another time! 


\section{I wish I could be brave enough.}

I suppose people hurt people in academia. In purpose or accidentally. During the workshop, I heard about the power game that is ongoing in academia. This game makes even the most experienced and highly respected professors to be afraid to speak out so that they would not sound stupid! I did not want to sound stupid or ignorant. I did not want to be 'revealed' as a person, who really does not have a right to be here with such a short history in the academic world. I noticed the vulnerability there, where I expected to see stable self-confidence. This was a relief to me because it made the academic world look more human to me. Is showing our vulnerability through experimenting different styles of academic writing a threat to us?

According to my observations during my short experience in the academic world, there is something hurtful in the appreciation of criticism. Although critical thinking is, in my opinion, a necessary practice to produce any new understandings and therefore new knowledge through research, it can be used in very harmful ways in the academic world between people. After listening to more experienced colleagues, it seems to me that criticality is too often used as a form of oppression or to support the individuals' place in the hierarchy. That is the opposite thing to what critical thinking tradition, in theory, was supposed to do (Duncum, 2008). The critical theory aims to break free from the prevailing and 'taken for granted truths,' but it is itself taken for granted in education literature (Duncum, 2008) and in academic practices in general.

'We honor others by challenging them when we think they are wrong, and by thoughtfully taking their criticisms of us. To do so is to take them seriously; to do any 
less is to dismiss them as unworthy of serious consideration, which is to say, to treat them with disrespect. Respect means the willingness to listen, openness to the possibility of learning from, responsiveness, criticizing when necessary. ---Respect does not mean that everything they do is "fine for them" or beyond the pale of critical judgment. Emphasis on the acceptance of difference is meant to express and encourage tolerance. Sometimes it succeeds in this. But sometimes it can have the opposite effect. Valorized differences can harden into Difference.' (Fay, 1996, 239)

\begin{abstract}
'Critical theory tends to operate from within the binary terms of dominance and a liberating counterpoint in which a singular truth is opposed by a singular alternative' (Duncum, 2008, 253). I think that this kind of confrontation as an accepted truth in academia does its silent work in us. It puts us to the positions of self-defence and makes us to focus on fighting for our existence in academia instead of creating a fruitful conversation. 'One truth colliding with another does not necessarily lead to enlightenment but to retreat, not to synthesis or compromise but to an endgame' (Duncum, 2008, 250). So how to criticize without hurting? How to take critic and avoid cutting vulnerability out of it?
\end{abstract}

\title{
Resistance as a fight or invitation to a dance?
}

Gilmore et al. (2019) are calling us to arms towards the positivist and normalized understandings of the only right way to do research. But is the war as a form of collective resistance that can really make space for difference and multiplicity in writing that Gilmore et al. (2019) want to achieve? I agree that fighting and defending oneself is sometimes necessary, but are there some other ways to create space for different forms of academic writing? 
I might be naiive and childish by saying this, but cannot we just do it? Write differently and by doing so, be the examples of how many kinds of forms of expressions in academic texts can create more understanding of the complex world we are living in? And with those texts invite the others, that might not accept this kind of writing as academic, to the dialogue? Are we, who want to defend the 'polyphony' of different ways of expressing research (Bakhtin, 1981 according to Duncum, 2008), able to understand or at least give space to the others that do not want to allow this plurality?

Could we somehow go beyond that attack-defence practice that is apparently experienced as hurtful in the academic world? Could we somehow just ask or persuade the partner, who thinks differently than us to join the common dance with us, get in the dialogue (Duncum, 2008) with us? Can we give space for the other who might want to stay still and not to dance with us? After all, we are all in the same 'academic ballroom' and any kind of expressions of movements in that space should be allowed.

I know your rules. I tried to play by your rules. Let's just try to play by different (my) rules. And then we will discuss it and agree on common rules. And I promise I will respect your choice.

This text is $y$-ours.

Being at this workshop in Helsinki, among colleagues who persist to ask the difficult questions even though there are no immediate answers, who understand and embody the need for safe inquiry spaces to emerge, and who create the moment where we can have conversations "for real", offers resistance in solidarity. It is pockets like this that give hope for another future in academia. 
And thus share, and thus resist...

And finally here I am, with all of you...not alone anymore...

I now feel that I know the answer:

I write to relate. I write to share. I write to live and to continue to live...

I write for me and for you ... with you...

Just add your voice. Free yourself. You are not alone. There are others to support you.

\section{Reflecting}

During the GWO workshop I noticed more clearly, how those who have been in academia for long have a kind of hard message for me who is just starting in this field: 'This work hurts me, this work makes me cynical and angry. It makes me not want to write anymore. It makes me want to resist it.' I did not have enough time to ask the questions: 'Why this work makes you angry? What things in academia make you cynical?' I guess that writing academic papers is sometimes so hard that it makes you want to quit, but I don't think that it is the reason that makes people cynical, angry and raises resistance against their work.

I noticed that on the first day it was not easy for me to talk about my thoughts among the more experienced colleagues. I think this happened, because of the respect that I felt for the experienced colleagues. I did not want to be 'revealed' as a person, who really does not have a right to be here with so short history in the academic world. At the time this happened, I did not really know why I felt this way. That's how I got caught in the practice that values highly 
the appreciation of the experience and some sort of hierarchy that is embedded in academic culture.

\section{Experiment survivor}

I decided to participate in a writing workshop organized by GWO and hosted by the GODESS Institute (Gender, organization, diversity, equality and social sustainability in transnational times) at Hanken in Helsinki. I entered the workshop with the 'standard' expectation of improving my writing, and in particular, writing of academic journal articles. I left the workshop realizing that I have started a new journey during the process of battling with the uncertainty and my own inertia through writing. We were quickly grouped with participants who haven't met before. My group is quite diverse in terms of academic background. It wasn't easy to produce a coherent idea for a small piece of writing given that we all have just met.

We discussed in our small group what we were resisting collectively in writing. Resistance against the dominant publishing regime, against Authorship with the capital A? Towards the end of the workshop, I came to realize that I was resisting my "old" self! No one has forced me to write for a particular journal, with a particular group of scholars, or even just to continue with the same way of writing. It has always been me who is not receiving all the other possibilities of writing. It's not easy to move out of the comfort zone that one has built. And this is just me in my $4^{\text {th }}$ year of academic job. What a terrifying thought to think what if I am just going on like a publishing machine. 
I also learnt how to write through vulnerability. As an Asian female, I have always tried to keep my head down. I blame Confucius for the bad influence of the 中庸philosophy (The Doctrine of the Golden Mean). I have learnt to just take on whatever comes to me and try not to talk about the negative, the challenging and most importantly the painful experiences. What a liberating moment for me to know that one can seek to heal by writing about these vulnerabilities in academia too. Reflecting on my research journey on the topic of gender, it suddenly became clear to me that I am strong enough now to face this issue straight on finally. I have been hiding behind the excuse that it would be too painful for me to research gender particularly in my country of origin. My academic father, a gender sociologist, has been so awfully gentle and kind to me when I continuously discarded gender by listing it as limitations in my PhD thesis, my articles (written mostly for job with as much of me in them as possible), and in my book (written for my interviewees who I didn't think would know how to care for gender). At this stage of my career, I am truly glad that I came to the realization that researching gender won't cause me more pain than the gendered phenomena around me have already caused it themselves. Instead it will be a way for me to heal my long term wound regarding gender since probably birth.

I heartfully thank the workshop organizers for their unconditioned authentic love in educating junior academics. As much as I felt like an animal being experimented on during the 1,5 day workshop, I have rediscovered so many important things not just for work, but also for life. I can now also joyfully claim that I understand the power and meaning of education.

\section{Solidarity}

Joining in and contributing to a workshop on collective writing left me with a sense of academic solidarity which still exists in today's academia dressed in a plethora of 
competition and pressure for productivity. Like Jenny Helin proposed in her presentation about the valuation, and recognition, of vertical time, so was the workshop a pause in the seemingly chronological timeline of academic work where junior researchers aim to one day become recognized senior researchers, perhaps professors, that are cited more, more and MORE, in order to be someone, to EXIST. The workshop embodied scarcity and unfinishedness, in its beauty - showing its participants how we are not alone in our struggles in the neoliberal academia.

Not only did it leave us with a sense of solidarity, it made us act: Alison Pullen's suggestion of actually becoming involved in collective act of resistance through writing made us to activate our hands, our minds, mouths, pens, laptop buttons - for a joint effort. While we started to work collaboratively to achieve a goal of sorts (an outcome to be sent for publishing in GWO), I dare to argue that it was more about being HERE and NOW. It was vertical time that we experienced - and, I suggest - we keep on experiencing, as we open our joint writing documents of our own group, carrying on writing. Carrying on, carrying on, pausing, pausing. To work as a collective cannot stand infinite carrying on without a time to pause, even it would manifest through our very own comprehension of it, and that is one of the reasons why collective writing is so powerful. It invites, perhaps forces, us to solidarity.

\section{Sensitivity}

Working on sensitive issues together is, well, sensitive. I believe in letting everyone speak, even if they speak against the grain. Then I see some others being offended and hurt. Sometimes I do not even see this, but I am reminded about it later. I know I should know better, and see, but time and again I am caught in this dilemma. When someone pours their 
heart out and there may be collateral damage, I am blind and clueless... because who am I to police others?

Perhaps time is again the great healer. Perhaps we need time. Writing, and writing together, is one way to heal; to bring multiple voices into the open, to converse, perhaps. We do not have to agree, but let's listen to each other and care. Even if we sometimes end up hurting each other. Because those who hurt have themselves been hurt.

\section{The academic picket line - or resisting 'Authorship' through collective writing}

Two interrelated themes emerged when exploring 'collective writing as a form of resistance.' First, we see collective writing as a resistance strategy against the prevalence of hierarchical articulations of academic Authorship and certain institutionalized discourses and interests. This resistance takes the form of collective writing as a form of picketing, a demonstration of solidarity through which writing becomes an embodied practice, and our writing-together marks an assemblage of bodies in solidarity. Second, by drawing upon tensions, power struggles and ambivalence within collective resistance, we suggest that collective writing may be considered a form of 'unionizing' that could help scholars better advocate marginalized issues, challenge dominant norms, rules and customs and promote care, respect and community within academia.

The following paragraphs are a collection of reflections and responses grounded in our experiences as early-career scholars with different disciplinary backgrounds, coming together in a workshop on writing, assembled to speak to and with each other. By mixing our voices, we explore possible strategies for a collective resistance against hierarchical articulations of 
individualized academic Authorship and knowledge production. Our focus is placed on discussing the challenges and possibilities in the collective construction of resistance against an Authorship, that is, the contemporary competitive logic of scholarly work, which has turned academic publishing into an individualized production line.

\section{One Authorship, One Academia?}

What is the soul of the text? Maybe a discussion around Authorship and the redistribution of academic capital - is that playing into and reproducing a capitalistic logic? There is something about a paradox; the horizontal and vertical that actually each serve purposes; we do not need to choose one. But by engaging with one, at a certain point in time (!), there is also a need for full, honest, true commitment to the cause; that is why we draw on the metaphor of picketing and the picket line that one collectively ensures is not crossed. Not by people who are, who belong to, who oppose, or just randomly walks by. It works to disrupt very concretely, but also takes up space, calls to it attention to spread, in the minds and in the practices of organizations that share similarities.

\footnotetext{
Already in this writing process, our voices start to mix. I read you, you read me, who are you, who am I? What remains a topic of uncertainty is the actual error in the current scene of academic publishing. What is so wrong about it that we want to stand in the picket line? It is a crucial question, as we probably all have been publishing and been excited to see our own names as authors of a particular piece of research and writing. It is a piece that embodies so much more effort that can be guessed from reading the typed words from a, usually electronic, paper. But when ready, who cares to protest or rebel? Can we not just adjust? Our answer is no, not really. To write collectively also speaks against the drawback of who actually benefits from an academic outcome. To write alone, or with two, three, or four
} 
colleagues - especially if you are not a big name in your 'field' and thus you are most assumedly insecure of whether your work will actually be read and, yes, cited - requires an effort that does not equal to the 'price' one gets when the work is eventually published.

We do not get direct compensation for our efforts. Our work is fueled by long temporalities and a wish of our works' recognition sometime in the future by our 'colleagues,' or strangers, who might be able to find our work from the jungle of academic publications (all of which nobody ever has the chance to go through in peace as we, at least many of us, are obliged to produce, produce, produce). Our work is fueled by a third-party benefit as well, as we feed the journals that feed us indirectly, and get their compensation for doing that. Yet, there is more complexity: our universities might form a block to this author $\rightarrow$ editor(s) of journal $\longrightarrow$ reviewers $\longrightarrow$ editor(s) $\longrightarrow$ author $\rightarrow$ journal $(\mathrm{x} 1,2,3,4) \rightarrow$ money to the journal through subscribers $\longrightarrow$ possible reputation through citations to the author / significant merit in the $\mathrm{CV}$ to get an academic position, by not allowing (cannot afford?) access to journals in which our work is published, thus blocking the distribution of our efforts to our own communities. So, the question “can we not just adjust?" is crucial: we simply cannot, even though we have to be part of the system to be alive as academics.

We need to be bold and brave. This means that we need to be ready to face the criticism regarding our statements as well. This is far easier to do when we write together - when we stand together - when we write as a collective. This does not mean hegemony. This means diversity and its embracement. This means multidisciplinary in its fundamental sense. Why? Why to write as a collective? What are our motivations to stand in the picket line? In a neoliberal world of academia, academic publishing counts as a quest and competition of 
individual academic capital. This is the enforcement and feeding of An Authorship. The big A.

Our first suggestion is to give away authorship by signing it over to anonymity. But that is nothing, it is not generative of academic capital, it does not resist the dominant discourse around Authorship, it just rejects it and take the conversation to a different space. One where authorship does not exist. A similar idea, that insists staying with, resisting or challenging dominant discourses on authorship, is one that does not turn over authorship to anonymity, but which turns it over to a collective, defined by individuals who turn over authorship. That is the union. Would it be possible to unionize; have one writing union that publishes, but still keeps track of authors. Allow the union to negotiate terms of publications, but also to redistribute capital among the members. By, for example, publishing member lists which shows the number of publications each member has published; or contributed through, through reviews, proofing or otherwise. Maybe citations are shared; maybe a reviewer is allowed a share in citations in terms of h-index; impact and so on.

In the case of writing in academia, we can form different fortresses by choosing with whom we write, to which journals we write, and advocate for the meaning in the texts that we produce as opposed to those produced by the 'other'. However, there is just one academia. It is a paradoxical Yin-Yang relationship because all the different kinds of writings co-exist together. With a white dot in the black half and a black dot in the white half, the collective whole of writings in academia are balanced.

While we pick our own picket line, we must also look beyond the line. As we march forward in the line, we do not forget that there is a bigger world out there. 


\section{We write. United.}

A picket line is a shared embodied space, where workers stake out common grounds to signal their needs for change and working conditions. It is a safe and protected space for individuals to advocate for things that matters to them. In a similar vein, academics need a safe haven to feel that we can write authentically what we think about issues. And this applies especially to academics who work on less dominant topics from marginalized perspectives. Collectively by standing in the picket line, we can resist towards the powerful established discourse of Authorship.

To stand in the picket line is not to try to destroy the system altogether at once - even though it can be an effort towards such aim. It is more about disrupting what is problematically normalized. It is about chewing one part of a bread and putting it back to the bag. Communal chewing! To stand in the picket line evokes communality which encourages academics, be they junior, senior, whatsoever, to take part in discussions possibly not one's 'specialty.' It gives room for learning from each other meanwhile it forms a united voice. A united voice that is multivocal at the same time. Paradoxical, yet necessary. A rainbow-colored, nonhegemonic voice of the union, affectively engaging with writing as picketing.

\section{Together}

As bell hooks reminds us: 'feminist theory is complex ... it is less the individual practice that we often think and usually emerges from engagement with collective sources' (1991, p. 3). In this spirit, we are writing resistance together. Co-writing is a practice shared with others to craft a message. Writing with others, with others in mind calls for negotiation, respect, and care. At times, it is necessary to set aside individual aims to accomplish this for the sake of 
clarity, to be coherent individuals have to conform, but within compromise and negotiation there is possibility for building on each other's ideas. Collective writing, as a resistance, enables us to produce something together, to face these challenges, both temporal, contentwise, and 'expertise'-bounded. It does not mean we would only write whatever comes to our minds - no. This piece of writing we are now producing together may not fulfil the requirements of a 'proper academic paper,' if you wish, entailing sections considering empirical fieldwork (if existing), analysis, positioning to a particular field of research, review of earlier work done, unfolding of the theoretical framework, discussion and conclusion. Nevertheless, it is a piece of writing that has enabled us to learn from each other, to affect each other, and hopefully also to affect others. This piece of writing is about suppressed thoughts and feelings that our collective picket line of many authors allows us to express without revealing ourselves as individuals.

\section{References}

Amrouche, C., Breckenridge, J., Brewis, D.N., Burchiellaro, O., Breiding Hansen, M., Hee Pedersen, C., Plotnikof, M. \& Pullen, A. (2018) Powerful writing, ephemera, 18(4): np. Bell, E., \& King, D. (2010). The elephant in the room: Critical management studies conferences as a site of body pedagogics. Management Learning, 41(4): 429-442.

Cixous, H. (1976). The Laugh of the Medusa. Trans. K. Cohen and P. Cohen. Signs, 1(4): $875-893$.

Duncum, P. (2008) Thinking critically about critical thinking: towards a post-critical, dialogic pedagogy for popular visual culture. International Journal of Education through Art, 4(3): $247-257$.

Ettinger, B.L. (2006). Matrixial trans-subjectivity. Theory, Culture \& Society 23: 218-222. Fay, B. (1996). Contemporary philosophy of social science. Oxford: Blackwell. 
Fotaki, M., Metcalfe, B. D., \& Harding, N. (2014). Writing materiality into management and organization studies through and with Luce Irigaray. Human Relations, 67(10): 1239-1263.

Gilmore, S., Harding, N., Helin, J. \& Pullen, A. (2019). Writing differently. Management Learning, 50(1): 3-10.

Grey, C. and Sinclair, A., (2006). Writing differently. Organization, 13(3): 443-453.

Helin, J. (2019). Dream writing: Writing through vulnerability. Qualitative Inquiry, 25(2): 95-99.

Helin, J., Harding, N. \& Pullen, A. (2020) Writing Differently. Dialogues in Critical Management series. Basingstoke: Emerald.

hooks, b. (1991). Theory as liberatory practice. Yale Journal of Law \& Feminism, 4, 1-12.

Kenny, K. \& Fotaki, M. (2015) From gendered organizations to compassionate borderspaces: Reading corporeal ethics with Bracha Ettinger. Organization 22(2): 183-199.

Kiriakos, C. M., \& Tienari, J. (2018). Academic writing as love. Management Learning, 49(3), 263-277.

Phillips, M., Pullen, A. \& Rhodes, C. (2014) "Writing organization as gendered practice: Interrupting the libidinal economy." Organization Studies 35(3): 313-333.

Pullen, A. (2017). Writing as Labiaplasty. Organization, 25(1): 123-130.

Pullen A. \& Rhodes C. (2008). Dirty Writing. Culture and Organization, 14(3): 241-59.

Rhodes, C. (2015). Writing organization/romancing fictocriticism. Culture and Organization, 21(4): 289-303.

Thanem, T. and Knights, D. (2019) Embodied Methodologies. London: Sage.

Ulmer, J.B. (2017). Writing Slow Ontology. Qualitative Inquiry, 23(3): 201-211. 